\title{
What have Eastern Kalahari Khoe languages lost linguistically?
}

\author{
Andy Chebanne \\ Faculty of Humanities, University of Botswana \\ E-mail: chebanne@mopipi.ub.bw
}

\begin{abstract}
Eastern Kalahari languages are spoken in the eastern parts of Botswana along the eastern fringes of the Kalahari Desert. These languages are closely related to the well-known and documented languages Glui and Gllana which are spoken in the west. From a historical linguistic perspective, Eastern Kalahari Khoe languages form a dialectal continuum within themselves and within Glui and G\|lana. In this continuum, several features in the domains of phonetics/phonology and morpho-syntax are reduced from west to east. Clicks are missing or modified in some cognates, and this variation is observed from the western dialects to the eastern ones:
\end{abstract}

$$
\begin{array}{ll}
\text { nキ₹ũũ (western) } \rightarrow \text { niũũ (eastern) } & \text { 'eat' } \\
\text { g!ãĩ (western) } \rightarrow \text { gãĩ (eastern) } & \text { 'ibex' }
\end{array}
$$

Morpho-syntactically, the presence of person-gender-number markers (PGNs) varies from the western dialects to the eastern ones:
(ii)

$\begin{array}{llll}\text { Kie kwa aba } & \text { sa } & \text { mũũ } \\ \text { 1SG PROG. dog } & \text { PGN-fem. } & \text { see } \\ \text { 'I see a dog' (female) } & \text { [western] }\end{array}$
(iii) Cie kwa apa mũũ
1SG PROG. dog see
'I see a dog' (gender unspecified) [eastern]

Some phonetic or phonological features, such as delayed aspiration, are modified while others are introduced, such as tonal depression. This paper will examine click loss, PGN attrition and other syntactic features and variations within this zone. Systematic comparisons of these linguistic features will be presented and appropriate analyses of processes discussed with a view to account for the (non-)occurrences of these features in this dialectal continuum. While language contact phenomena may precipitate some of these feature losses, it is the thesis of the paper that there is an apparent regularity in some of these morpho-syntactic variations. The ultimate aim of this paper is to answer the question, "What have these languages lost linguistically?"

Keywords: Khoisan languages, clicks, phonetics/phonology, morpho-syntax, PGN, Botswana 


\section{Introduction}

The Eastern Kalahari speech communities that are targeted for discussion are Cua, Kua, and Tsua. These language varieties are historically found from within the Central Kalahari Game Reserve of Botswana and towards the eastern parts of the Reserve into the Western Sandveldt of the Central District towards Lephephe, Shoshong, Serowe and Madinare. The designation "Eastern Kalahari Khoe" is used by Chebanne and Nthapelelang (2000; see also Vossen 1997:386) in their genetic classification of Khoe languages. These languages are spoken in North-Central Botswana, to the east towards the Shashe river in the north-eastern part of the country, and even in Eastern Zimbabwe (Cashdan 1979). Historical accounts of these ethnic communities indicate that they have lived there for thousands of years (cf. Dornan 1917, Cashdan 1979, Dowson and Lewis-Williams 1994), however, historical and linguistic research has often provided varying accounts of these Khoisan ethnic groups. Administratively, in Botswana, there is little mention of these communities except inferences in the Government Remote Areas Dwellers' Programmes which aim to uplift their lives (cf. Lane, Hermans and Molebatsi 2001; Molebatsi 2001). Linguistically, however, their languages should be considered endangered.

Generally, the Khoisan communities in Botswana have up to now been handled in a manner that has not facilitated their individual recognition as independent ethnic entities with their inalienable right to self-actualisation through ethnic and language identity. This is also applicable in terms of the way their languages have been treated. If there is a general reference to Basarwa (Khoisan) and Sesarwa (language), there is no understanding of the diversity and specificity of these Khoisan communities in all the areas that they inhabit. Consequently, their numbering and even studies on their language and culture have been rendered difficult.

The importance of this problem of language endangerment and marginalisation is fundamental as indeed the confusion of Khoisan ethnonyms (ethnic names) and glossonyms (language names) means that the classification will also be confused; for example, Grimes' Ethnologue (2008), just presents lists of names without a distinction of their ethnic and linguistic particularity. Ethnologue's lists of language names must have been based on earlier studies in the area (e.g. Schepera 1930; Westphal 1971), and also recent ones (e.g. Andersson and Janson 1997). These lists present some difficulties in that it is not clear what they designate, linguistically or ethnically. The following is a modified language-class listing of what corresponds to Eastern Kalahari Khoe, according to Grimes (2008).

(1) Eastern Kalahari Khoe handling in some socio-historical texts

a. SHUA (spoken by the SHUA-KHOE, 12 000). The language belongs to the Eastern Khoe (Voegelin and Voegelin 1977, Hasselbring 2001, Chebanne 2001). Central and Northwest districts, Nata., Southern Africa, Central, Tshu-Khoe, North Central. It is closely related to CUA and KUA. Dialects: DETI (spoken by the Deti Khoe); DANISI (spoken by the Danisani). Belongs under SHUA to the Eastern Khoe Ethnic and glossonyms prevalent in the area. Reported to be endangered. Survey needed.

b. TSHOA (TSHWA) (variant of CUA, spoken by the G//abake-Ntshori, KhoeEtshori, Hiechware, 9 000). The language belongs to the Eastern Khoe (LBT 1995, Chebanne 2001, Voegelin and Voegelin 1977). Nata, Tati, Serule, Mosetse, Mokubilo, Matsitama, Mmashoro, and Mancotai., Southern Africa, Central, TshuKhoe, North Central. 
c. CUA (TSUA) (spoken by the Cuare or Cuara). Belongs to the Southern Eastern Khoe.

d. KUA(spoken to the south and to the west of Serowe and around Shoshong) (Voegelin and Voegelin 1977, Johnstone 1976). Southern Africa, Central, Tshu-Khoe, Northeast. Nomadic. Hie Chware, Khoe-Etshori, and KOSSEE are possible dialects. Traditional religion, Christian. Survey needed.

While Ethnologue provides these extensive location and variety details, there are nonetheless two critical observations that can be made: (i) there is no indication of the inter-relationship between the Shua and the Tsua (or Tshwa, perhaps further to the east), and (ii) there is clearly a geographical overlap in the distribution of these ethnic communities in the identified locations. In the following sections, these questions regarding linguistic relationships will be examined and some clarity provided. The map below helps to roughly locate the Khoisan ethnolinguistic communities under discussion. They are more or less located in the region of 24E and $28 \mathrm{E}$ longitude, and 20S and 24S latitude.

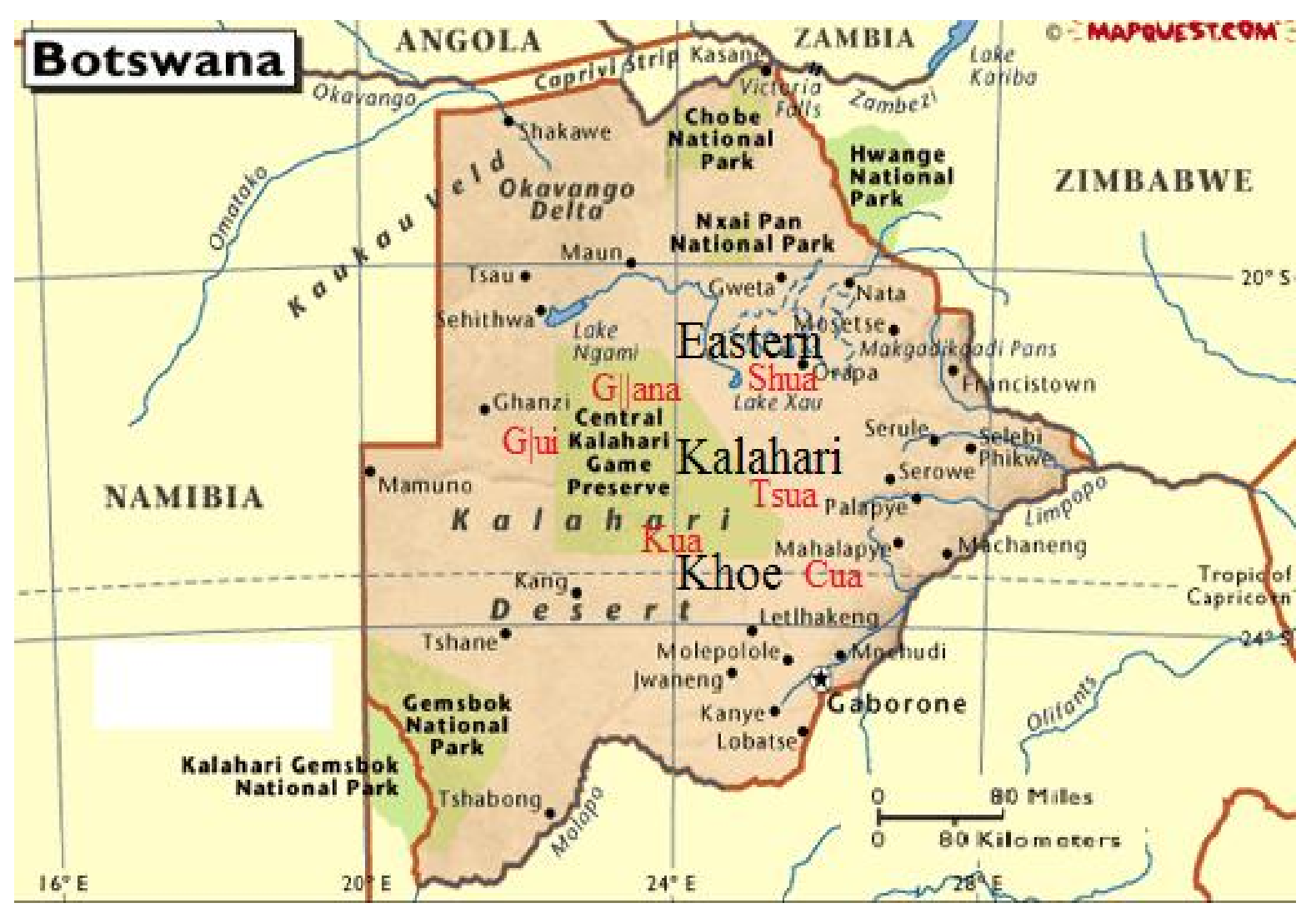

Figure 1. Locations of Eastern Kalahari Khoe languages (modified from MapQuest.com)

\section{The Eastern Kalahari Khoe in Khoisan classification}

Recent surveys and linguistic research that have brought about some clarity in the linguistic relationship of the Khoisan communities in the area have been undertaken by Vossen (1988), and others contained in the publications by Vossen and Keuthmann (1986) and Güldemann and Vossen (2000). Figure 2 summarises the commonly accepted classification and the tentative Khoisan language families (Vossen and Keuthmann 1986, Vossen 1988, Güldemann and Vossen 2000, Chebanne 2003, Du Plessis 2009). In this classification, it should be noted that 
"San" is not used in its linguistic sense to denote a particular linguistic grouping; rather, it is used in this paper in its popular sense, purely as a matter of convenience (cf. Güldemann and Vossen 2000).

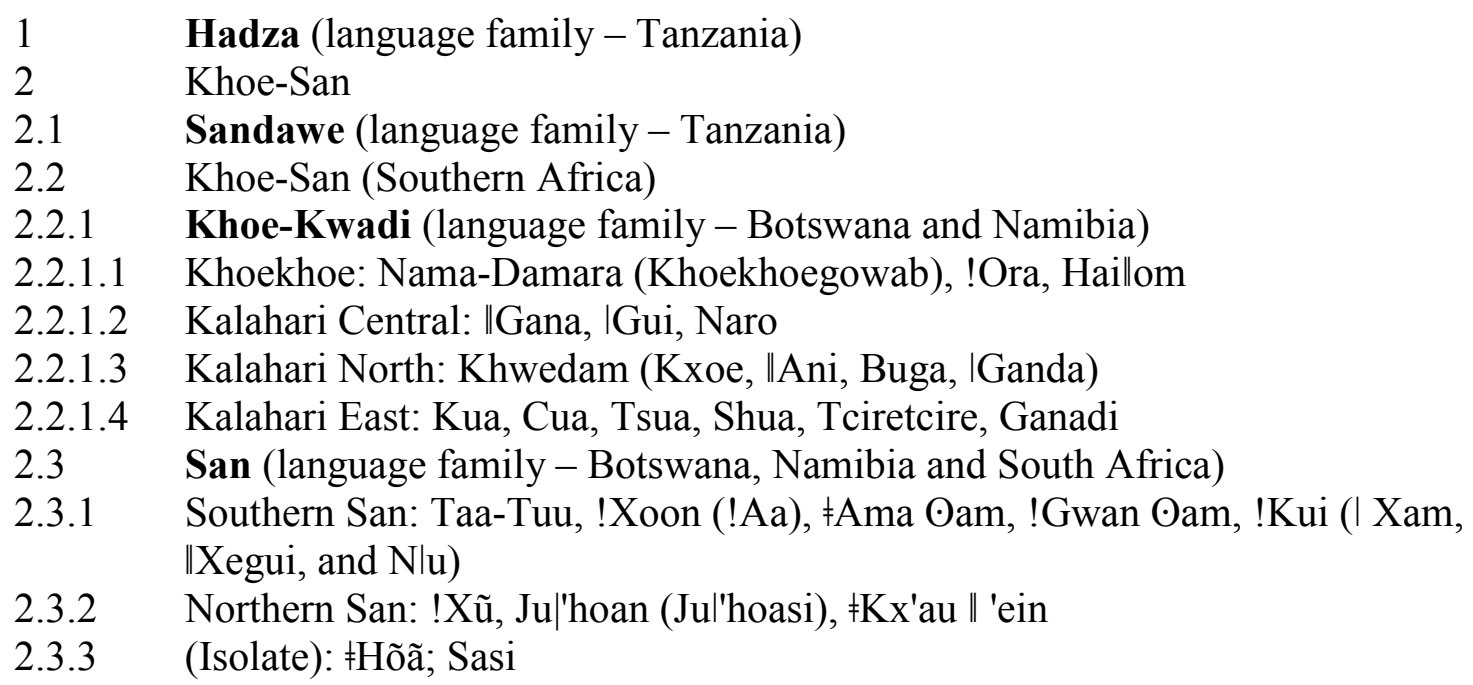

Figure 2. Khoisan languages classification - The Khoe and San language families

The Eastern Kalahari Khoe languages are in 2.2.1.4 in this figure. Within this group, there are others, but they are not the subject of the present discussion. While Kua appears as a language in the figure, the view taken in this paper is that the term "Kua" is an endogenous label for all of these languages. The data on Kua that will be presented later on should be regarded as that of a Gllana sub-lect. However, the speakers from whom the data was taken insisted on referring to themselves as "Kua".

Figure 3 attempts to locate and zone the current distribution of Khoisan speech communities and the Eastern Kalahari Khoe languages in Botswana. As can be observed in the shadings, some of the communities are found across borders, especially to the west of Botswana. The Eastern Kalahari Khoe languages found in eastern Botswana also spill over into Zimbabwe. The eastern part of Botswana is where the current research activities on these languages are focused. However, this could also include different dialectal varieties of Tsua or Tshwa. As Figure 3 shows, within this wide eastern zone it is possible that these communities, wherever they are found, may be highly dialectalised to the extent that they may not be readily intelligible to each other. 


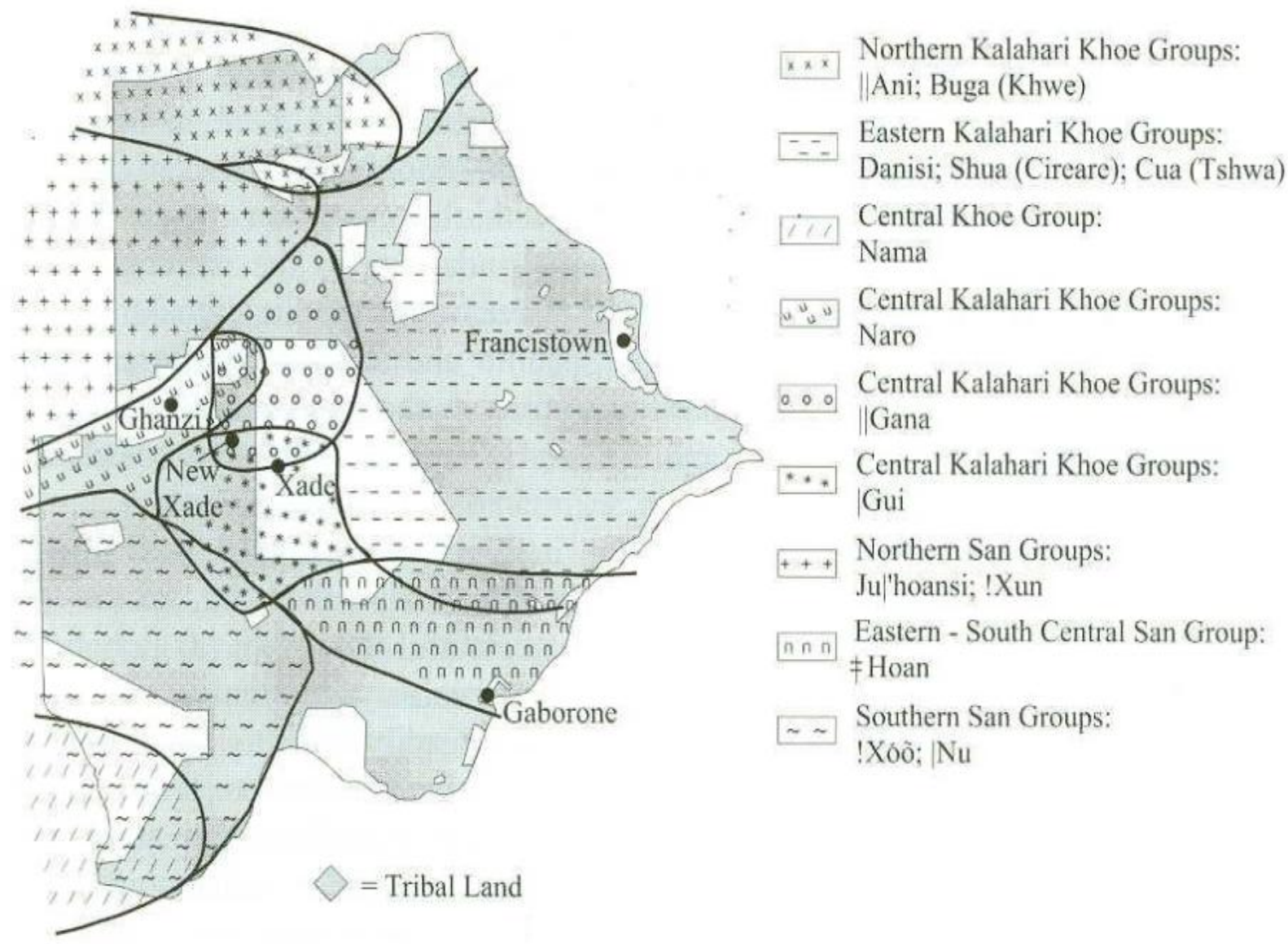

Khoisan ethnolinguistic groups and their localities and habitation in Botswana

Sources: Anderson \& Janson, 1997; Chebanne \& Nyati-Ramahobo, 2003; Güldemann \& Vossen, 2000; Köhler, 1971; Nakagawa, 1996; 2006; Silberbauer, 1965; Tanaka, 1980; Trail, 1986; Westphal, 1962.

Figure 3. Eastern Kalahari Khoe focus research areas (Chebanne 2008)

\section{Phonological particularities of Eastern Kalahari Khoe}

Data collection for the phonological discussion took place during 2012 and 2013 from the Eastern Kalahari Khoe varieties of Kua (a variant of G\|lana), Tsua and Cua. A word list of 150 terms was prepared, all of which have been checked against Glui, the western variety. Phonological particularities are defined here as those features that characterise the Eastern Kalahari Khoe languages and therefore set them apart from their sister languages to the west. Phonologically speaking, Kua, Cua and Tsua have a click inventory comparable to most of the related languages in the west. However, these varieties tend to have fewer complex accompaniments to clicks (see Nakagawa 2006). Table 1 details the sound inventory of Kua, Tsua and Cua (modified from Nakagawa 2006). 
Table 1. The sound inventory of Kua, Tsua and Cua (modified from Nakagawa 2006)

\begin{tabular}{|c|c|c|c|c|c|c|c|c|c|c|}
\hline & bilabial & dental & alveolar & lateral & $\begin{array}{l}\text { alveo- } \\
\text { palatal }\end{array}$ & $\begin{array}{l}\text { alveo- } \\
\text { palatal }\end{array}$ & palatal & $\begin{array}{c}\text { palatal } \\
\text { cons. }\end{array}$ & Velar & uvular \\
\hline \begin{tabular}{|l} 
voiceless \\
stops
\end{tabular} & $\mathrm{p}$ & | & $\mathrm{t}$ & $\|$ & $!$ & ts & $\neq$ & $\mathrm{c}$ & K & $q$ \\
\hline $\begin{array}{l}\text { aspirated } \\
\text { stops }\end{array}$ & & h & th & $\| \mathrm{h}$ & $! h$ & tsh & $\ddagger$ fh & ch & $\mathrm{Kh}$ & qh \\
\hline \begin{tabular}{|l} 
delayed \\
aspiration
\end{tabular} & & l'h & & $\|$ 'h & !'h & & $\neq$ 'h & & & \\
\hline \begin{tabular}{|l} 
ejective \\
stops
\end{tabular} & & l' & $t^{\prime}$ & $\| ’$ & !' & ts' & $\ddagger^{\prime}$ & $c^{\prime}$ & $\mathrm{k}^{\prime}$ & $q^{\prime}$ \\
\hline glottalised & & 12 & & $\|_{2}$ & $! 2$ & & $\ddagger 2$ & & & \\
\hline \begin{tabular}{|l|} 
voiced \\
stops
\end{tabular} & $\mathrm{b}$ & $\mathrm{g}$ & d & $g \|$ & $\mathrm{g} !$ & $\mathrm{dz} \quad \mathrm{j}$ & $g \neq$ & $\mathrm{J}$ & $\mathrm{G}$ & \\
\hline affricates & & $\mid \mathrm{x}$ & tx & $\| \mathrm{x}$ & !x & tsx & $\neq \mathrm{x}$ & & $\mathrm{kx}$ & $\mathrm{qx}$ \\
\hline $\begin{array}{l}\text { uvular } \\
\text { stops }\end{array}$ & & lq & & $\| \mathrm{q}$ & $! q$ & & $\neq q$ & & & \\
\hline $\begin{array}{l}\text { ejected } \\
\text { uvulars }\end{array}$ & & lq' & & $\| q^{\prime}$ & $! q^{\prime}$ & & $\neq q^{\prime}$ & & & \\
\hline $\begin{array}{l}\text { aspirated } \\
\text { uvular click }\end{array}$ & & lqh & & $\| \mathrm{qh}$ & !qh & & $\neq q h$ & & & \\
\hline \begin{tabular}{|l|} 
ejective \\
affricates
\end{tabular} & & $\begin{array}{c}\text { lx' } \\
\left(\mid \mathrm{qx} x^{\prime}\right)\end{array}$ & tx' & $\begin{array}{c}\| x^{\prime} \\
\left(\| q x^{\prime}\right)\end{array}$ & $\begin{array}{c}\text { !x' } \\
\left(! q x^{\prime}\right)\end{array}$ & ts $x^{\prime}$ & $\begin{array}{c}\neq \mathrm{x}^{\prime} \\
\left(\neq \mathrm{qx} \mathrm{x}^{\prime}\right)\end{array}$ & $\mathrm{cx}$ & $\mathrm{kx}{ }^{\prime}$ & $q x^{\prime}$ \\
\hline nasals & $\mathrm{m}$ & $\mathrm{n} \mid$ & $\mathrm{n}$ & $\mathrm{n} \|$ & $\mathrm{n} !$ & & $\mathrm{n} \neq$ & & & \\
\hline fricatives & & & & & & s $\quad \mathrm{Z}$ & & & & $\mathrm{x} h$ \\
\hline lateral & & & $1 ; r$ & & & & & & & \\
\hline
\end{tabular}

As can be observed, the consonant systems of these languages are still intact and comparable to the rest of Central Khoisan. However, a more detailed study is needed to create a definitive classification of the sound system of Eastern Kalahari Khoe. Nakagawa's (2006) study has helped to identify some of these sounds and to classify them appropriately.

As mentioned earlier, a comparative word list of 150 items taken from the three languages and checked against Glui was the basis for the phonetic and phonological study. The inclusion of Glui, which is from the western zone of Kalahari Khoe, helps us to understand the genetic and diachronic phonological issues that are observed, since these languages belong together in the Kalahari Khoe (Vossen 1988, Güldemann and Vossen 2000). Observed changes or differences from Glui are therefore crucial in this study. The comparative approach is important for this paper as it will help to argue the case of click loss or otherwise. As Traill and Vossen (1997:26) state, "the systematic nature of click loss can only be identified through comparative data".

It is clear from the comparative word list that the fundamental clicks $[1, !, \|, \neq]$ are present in all the speech communities, but their occurrences vary statistically. While these fundamental clicks are attested in all these languages, they do not necessarily appear in the cognates. The examples 
in (2) are cognates that retain the same click types.

(2)

Retained clicks
a. I' huru $\mathrm{HM}^{1}$ (Kua, Cua, Tsua, Glui)
b. g\|uu HH (Kua, Cua, Tsua, Glui)
c. ¥'heru HH (Kua, Cua, Tsua, Glui)
d. Iam HH (Kua, Cua, Tsua, Glui)
e. glaa HL (Kua, Cua, Tsua, Glui)

'to undress'

'to build a fire'

'to be given a gift (when visited)'

'sun, day'

'Siler tree (Terminalia Sericea)'

The retained clicks across the languages and within the Eastern Kalahari Khoe are $[\|],[I]$ and $[\ddagger]$. The alveolar click [!] seems to be less common across these languages. Furthermore, in certain cases, there are changes that can be observed, as in the examples in (3):

Evolutions and changes in common shared clicks
a. g\|úū HM (Kua, Cua, Glui) $\rightarrow$ |ruu HM (Tsua) 'chest'
b. yllaro HL (Kua, Cua, Tsua) $\rightarrow$ glan HH (Glui) 'to carry meat on the shoulders'
c. \|qhua HL (Kua, Glui) $\rightarrow$ łqhua HL (Cua, Tsua) 'to chop the game head to cook it'

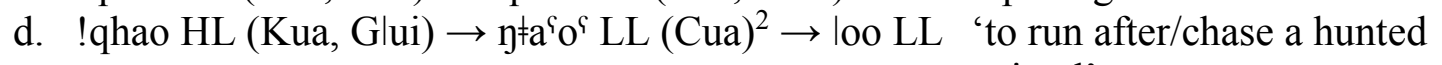 animal'

In these examples, the loss of systematic click correspondence is mainly divided between Kua and Glui, and Cua and Tsua. In certain cases where cognates are traceable or recognisable, their clicks are different or do not exist. In some cases it is the loss of cognates and the acquisition of the new lexicon that are responsible for the loss of systematic click correspondence. In other instances, the click seems to be lost without any evident phonological trigger, as in the examples in (4).

Click loss without evident phonological triggers
a. yabe $\mathrm{MM}(\mathrm{Kua}) \rightarrow$ gabe $\mathrm{MM}$ (Cua, Tsua) $\rightarrow$ n! abe MM (Glui)
b. yoe $\mathrm{HM}$ (Kua) $\rightarrow$ gue $\mathrm{HM}$ (Cua, Tsua) $\rightarrow$ n! oe HM
c. yaro HL (Kua) $\rightarrow$ garo HL (Cua, Tsua) $\rightarrow$ n! aro
d. yuu HM (Kua) $\rightarrow$ dzuu HM (Cua, Tsua) $\rightarrow$ n! uu HM (Glui)
e. nłuu HH (Kua, Cua) $\rightarrow$ nũũ HH (Tsua) $\rightarrow$ nłũũ HH
'giraffe' 'porcupine' 'chameleon' 'a house, hut' 'to sit'

In the examples in (4), it is clear that the alveolar click [!] seems to have undergone click loss in the eastern varieties Kua, Cua and Tsua. In the examples in (5), the loss of [ $y$ !] results in either a simple velar nasal or a velar stop.

Loss of $y$ !
a. pua LL (Kua) $\rightarrow$ kua LM*(LL) (Cua, Tsua) $\rightarrow$ n! ua LL (Glui)
'duiker'
b. yare LL (Kua) $\rightarrow$ kare LM*(LL) (Cua, Tsua) $\rightarrow$ n! are LL
'foot'
c. yaro HL (Kua) $\rightarrow$ garo HL (Cua, Tsua) $\rightarrow$ n! aro HL (Glui)
'chameleon'

\footnotetext{
${ }^{1} \mathrm{H}=$ high tone, $\mathrm{M}=$ medium tone, $\mathrm{L}=$ low tone, $\mathrm{HH}=$ two high tones, $\mathrm{HM}=$ high and medium tones, $\mathrm{HL}=\mathrm{high}$ and low tones, $\mathrm{LL}=$ low tones, $\mathrm{MM}=$ two medium tones.

2 Note that the items in this example are not cognates.
} 
d. yabe $\mathrm{MM}(\mathrm{Kua}) \rightarrow$ gabe $\mathrm{MM}$ (Cua, Tsua) $\rightarrow$ n! abe MM (Glui)

'giraffe'

e. gãĩ HM (Kua, Cua, Tsua) $\rightarrow$ g!ãĩ HM

'ibex'

In the phonological examination of the comparative list alluded to earlier, there are certain phonological features that may help to explain some instances of click loss or modification. Some of these features include palatalisation, aspiration (regular or delayed), and nasalisation of some vowels. It is not clear if velarisation plays any role, but it seems to be a result of some of the instances of click loss.

\subsection{Palatalisation}

Palatalisation commonly refers to sound articulation associated with tongue movement towards the hard palate. It could be considered a particular process that assimilates certain consonants in the context of certain vowels to the palatal zone of articulation. Palatalisation seems to play a very important role in click loss. The associated aspiration may also be crucial in this sound change process. The following examples in (6) illustrate.

\section{Palatalisation as impetus of click loss}

a. $\neq$ hee- $\neq$ here HH HL (Kua, Cua, Glui) $\rightarrow$ chee HH (Tsua) 'to drop something powdery on a surface'

b. khuo HH (Kua) $\rightarrow$ khoo HH (Cua, Tsua (depress)) $\rightarrow$ ! hoo HH (Glui) 'the beginning of the hot season'

c. khui HM (Kua, Cua, Tsua) $\rightarrow$ !hui HM 'to pierce and make a hole'

d. łhura HL (Kua, Glui) $\rightarrow$ chura HL (Cua) $\rightarrow$ tshura HL (Tsua) 'to unroll something'

e. łrũũ HH (Kua, Glui) $\rightarrow$ ł₹ũũ HH (Cua) $\rightarrow$ jũũ HM (Tsua) 'to eat (beans, etc.)'

f. cum HL (Kua, Cua) $\rightarrow$ tum HL (Cua, Tsua) 'to eat'

As is clear in these examples, high and lax vowels tend to be the ones associated with resultant palatalised sounds. This palatalisation is sometimes extensive, that is, it goes beyond palatalisation to result in velar sounds. At the surface level, palatalisation that seems to yield velar sounds may be considered irregular, however, these sounds must first have been palatalised in the intermediate stage. The example in (7) illustrates the likely phonetic process.

$$
\begin{aligned}
& \text { Irregular palatalisation process } \\
& \begin{array}{ll}
\ddagger \mathrm{h} \rightarrow \mathrm{t} & \rightarrow \mathrm{tsh} \\
! \mathrm{h} \rightarrow \mathrm{t} & \rightarrow \mathrm{kh} \\
\neq \mathrm{h} \rightarrow \mathrm{y} &
\end{array}
\end{aligned}
$$

As (6) and (7) illustrate, some cognates remain at the palatal stage; what extends this sound change to affrication and velarisation is not clear at this stage of analysis. However, the data presented here confirms the well-known pattern of click absence in eastern Kalahari varieties of Khoe when compared with western and Khoekhoe varieties, and is generally assumed to reflect a process of click loss.

The standard explanation for the phenomenon of click loss is the account given by Traill and Vossen (1997:30), where a model of phonetic "weakening" is invoked. However, the data provided in (8) clearly shows that these language varieties still attest the stage of conservation. 
The lexicon also shows that there are instances of click replacement with egressive consonants, such as [!] replaced with [k], and [ł] with [c].

\begin{tabular}{|c|c|c|c|c|}
\hline Dental & Alveolar & Lateral & Palatal & \\
\hline I & $!$ & $\|$ & $\neq$ & Stage of click conservation \\
\hline I & $\begin{array}{l}! \\
\downarrow \\
\mathrm{k}\end{array}$ & $\|$ & $\neq$ & Stage of [!] and [k] neutralisation \\
\hline | & $\begin{array}{l}! \\
\downarrow \\
\mathrm{k}\end{array}$ & $\|$ & $\begin{array}{l}\neq \\
\downarrow \\
\mathrm{c}\end{array}$ & Stage of $[\ddagger]$ and $[c]$ neutralisation \\
\hline
\end{tabular}

The loss or replacement of the alveolar and palatal clicks is accounted for by Traill and Vossen (1997:23). The authors demonstrate that the abrupt nature of these clicks and the force used in their articulation make them targets for replacement by non-click consonants. This situation characterises the Cua-Kua-Tsua continuum where there is neutralisation between [!] and [k], and $[\ddagger]$ and $[\mathrm{c}]$. The accompaniments of clicks also facilitate click loss, as the following section will illustrate.

\subsection{Regular and delayed aspiration}

All languages in the Eastern Kalahari Khoe continuum make the distinction between regular and delayed aspiration. Delayed aspiration vents some air into the nasal cavity and gives an impression of nasalisation. However, due to click loss, it is systematically lost in some cognates of Cua and Tsua. Regular aspiration seems not to cause any sound changes.

(9) Regular aspiration
a. "Nhaba HL (Kua, Cua, Tsua (depress), Glui) 'to stumble or stagger'
b. "lhobe HL (Kua, Cua, Tsua (depress), Glui) 'to creep (toward)'
c. Ihumi HL (Kua, Cua, Tsua (depress), Glui) 'to wear an apron between the legs'
d. Iqham HL (Kua, Cua, Tsua (depress)) 'silky spider thread'
e. \|qhua HL (Kua, Cua, Tsua, Glui) 'to chop a head of game to cook it'

In words with regular aspiration, all languages in the continuum retain the aspiration without sound changes. However, the following examples in (10) show how delayed aspiration presents itself and the differences that cognates present in different languages.

(10) Delayed aspiration
a. !'hubu HM (Kua, Glui) $\rightarrow$ guu MM (Cua) $\rightarrow$ tshuu MM (Tsua) 'to be swollen'
b. " 'ha' ${ }^{\varsigma} i^{\varsigma} \mathrm{HL}$ (Kua, Glui) $\rightarrow \mathrm{dza}^{\mathrm{c}} \mathrm{m}$ LH (Cua, Tsua) 'a whip'
c. \|'hao HL (Kua, Cua, Glui) $\rightarrow$ \|hao HL (Tsua) 'to throw seeds/water nimbly'
d. ’hãã MM (Kua, Glui) $\rightarrow$ łĩã HL (Cua) $\rightarrow$ zĩã HL (Tsua) 'to lead; to go ahead'
e. $\ddagger$ 'hara HL (Kua, Glui) $\rightarrow$ |xari LL (Cua) $\rightarrow$ łqhua LL 'to cut long and thin; thinly cut'
f. ł'here HL (Kua, Cua, Glui) $\rightarrow$ łhĩi HL (depress) 'to move by poking' 
Tsua is the most flexible with regard to delayed aspiration. In the sound changes, the resulting consonant is simply aspirated or, in certain instances, vowels are nasalised. Regular aspiration and nasalisation may easily derive from delayed aspiration. This is so because the necessary slight nasal venting may yield to full nasalisation and then normalise the aspiration, as illustrated in (11).

(11) Loss of delayed aspiration and normalisation of aspiration

$$
\begin{aligned}
& \neq^{\prime} h \rightarrow \neq h \\
& \|' h \rightarrow\| h
\end{aligned}
$$

In the eastern dialects, once this normalisation of aspiration is achieved, the click can be dropped. In certain instances, there is an emergence of nasalisation when delayed aspiration is lost, as will be explained in the following section.

\subsection{The emergence of nasalisation}

As can be seen from the examples in (10), nasalisation that emerges in certain cognates stems from delayed aspiration. The examples in (12) demonstrate the particular nature of the resultant nasalisation.

(12) Emergence of vowel nasalisation
a. ł’here HL (Kua, Cua, Glui) $\rightarrow$ łhĩî HL(Tsua)
'to move by poking'
b. ’hãã MM (Kua, Glui) $\rightarrow$ fĩã HL (Cua) $\rightarrow$ zĩã HL (Tsua) 'to lead; go ahead'
c. ‡'han HM (Kua, Glui) $\rightarrow$ khãã LL (Cua, Tsua) 'to set a trap'

Vowel nasalisation loss and gain seem to be at play in most of the examples in (11). However, in some instances, a nasal consonant emerges. The examples in (13) illustrate how vowel nasalisation loss and gain results in nasal consonants.

(13) Emergence of nasal consonants
a. Ihãã HL (Kua, Glui) $\rightarrow \mid a^{\uparrow} n^{\varsigma}$ a HL (Kua) $\rightarrow$ lana LL (Cua) $\rightarrow$ ana LL (Tsua) 'wood/branches around a quarry/prey'

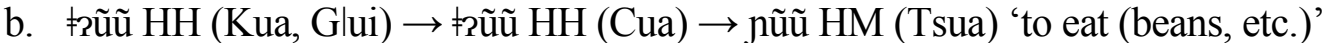
c. $\quad$ cum HL (Kua, Cua) $\rightarrow$ tum HL (Cua, Tsua) 'to eat'
d. mra LHL (Kua, Tsua) $\rightarrow$ mma HLL (Cua) $\rightarrow$ mãã LM (Glui) 'a head'

These examples show that the loss or gain of vowel nasalisation also results in the loss or gain of other phonetic features, such as aspiration and glottalisation. Nasal segments or features can also be completely modified in Cua and Tsua. In the examples in (13), nasalised alveolar clicks correspond to cognates with only velar nasals; this is also the case where clicks are lost.

(14) Loss of nasalisation
a. yua LL (Kua) $\rightarrow$ kua LM*(LL) (Cua, Tsua) $\rightarrow$ n! ua LL (Glui) 'duiker'
b. yare LL (Kua) $\rightarrow$ kare LM*(LL) (Cua, Tsua) $\rightarrow$ n! are LL (Glui) 'a foot'
c. yaro HL (Kua) $\rightarrow$ garo HL (Cua, Tsua) $\rightarrow$ n! aro HL (Glui) 'chameleon' 

d. yabe MM (Kua) $\rightarrow$ gabe MM (Cua, Tsua) $\rightarrow$ n! abe MM (Glui)
'giraffe'
e. gãĩ HM (Kua, Cua, Tsua (depress)) $\rightarrow$ g!ãĩ HM (Glui)
'ibex'

Example (14e) also seems to indicate that voiced clicks in Kua, Cua and Tsua are lost in favour of a velar consonant.

\subsection{Vocalism}

As is evident in the examples in (13) and (14), vowels play an important role in sound changes in these four languages. This section presents changes associated with vowels in this language continuum. Vowels in these languages can be simple, nasalised, pharangealised or associated with glottal stops.

Vowel changes
a. nllaa HL (Kua, Cua, Tsua) $\rightarrow$ nlãã HL (Glui) 'horn'
b. $a^{\varsigma} a^{\varsigma}$ LL (Kua, Cua, Glui) $\rightarrow$ habe HM (Tsua) 'to arrive'
c. k'ãĩ HH (Kua, Glui) $\rightarrow$ c'î̃ HH (Cua, Tsua) 'liver'

Vowels therefore participate in the phonological intervariability of the sound system of these speech communities. However, they remain relatively stable when compared with other phonological elements such as egressive and ingressive consonants. Nonetheless, much more research needs to take place in order to understand the complete vocalism of these languages and how it plays a role in the tonal shape of segments. One aspect that could be pursued is the role of tone in vowel behaviour which, at this stage, is not evident. However, some tonal properties are considered in the following section.

\subsection{Tone}

Tone plays an important role in Khoisan languages (see Nakagawa 2006). The Eastern Kalahari Khoe languages make six tonal distinctions. The examples in (16) present the six tonal melodies that Nakagawa (2006) identified in the languages of the Kalahari Khoe group. The comparative list of 150 words alluded to earlier, clearly showed that Cua, Kua and Tsua presented similar tones, and therefore similar tonal melodies, as Glui.

(16) Tonal classes of Eastern Kalahari Khoe languages
a. lui HH (Kua, Cua, Tsua, Glui)
b. $\| x o r e ~ H M(K u a$, Cua, Tsua) $\rightarrow \|$ xobe HM (Glui)
c. Iam HL (Kua, Cua, Tsua, Glui)
d. łqai LH (Kua, Cua, Tsua) $\rightarrow$ łqai LM (Glui)
'[num.] one'
'to open/uncover'
'[num.] two'
e. qx'ura MM (Kua, Cua) $\rightarrow$ qx'ora MM (Tsua) $\rightarrow$ qx'ua (Glui )MM 'unripe'
f. pua LL (Kua) $\rightarrow$ kua LL (Cua, Tsua) $\rightarrow$ n! ua LL (Glui) 'duiker'

While tonal shapes may be maintained, they may not have the same phonetic quality. For instance, the word for 'cow', /gube/ in the west and /dzube/ in the east, are both HL but, phonetically and relatively, /dzube/ has a depressed $\mathrm{H}$ tone. The source of this depression seems to be triggered by the voiced consonants in the eastern varieties. Voicing therefore causes some 
tonal depression in Tsua but less so in Cua. Most of the targets for depression are the HL and HM tone classes.

(17) Tonal depression

a. Nhaba HL (Kua, Cua, Tsua (depress), Glui) 'to stumble and stumble; stagger'

b. Whobe HL (Kua, Cua, Tsua (depress), Glui) 'to creep (toward)'

c. Ihumi HL (Kua, Cua, Tsua (depress), Glui) 'to wear an apron between the legs'

d. "qham HL (Kua, Cua, Tsua (depress)) 'silky spider thread'

It should be noted that there is no tonal depression in Kua and Glui in similar phonetic contexts as with Cua and Tsua. The conclusion to be made at this stage of analysis is that tonal depression is an emerging phonetic feature in the eastern varieties of the Eastern Kalahari Khoe languages. It can be said that tonal depression is associated in these eastern varieties with voicing and aspiration, as exemplified in (18). Voiced stops and aspiration seem to be responsible for tonal depression.

(18) Tonal depression triggers

a. tshaa HM (Kua, Cua, Glui) $\rightarrow$ tshaa HM (Tsua (depress)) 'water'

b. tshiu HM (Kua) $\rightarrow$ tshau HM (Cua, Tsua (depress)) $\rightarrow$ tshiu HM (Glui) 'hand'

c. chuu HH (Kua, Glui) $\rightarrow$ thuu HH (Cua, Tsua (depress)) $\rightarrow$ thuu ka MM L 'yesterday'

d. jibe $\mathrm{HH}(\mathrm{Kua}) \rightarrow$ debee $\mathrm{HH}$ (Cua, Tsua (depress)) $\rightarrow$ jibe HH (Glui) 'lower lip'

e. yuu HM (Kua) $\rightarrow$ dzuu HM (Cua, Tsua (depress)) $\rightarrow$ n! uu HM (Glui) 'house, hut'

However, in some cases, depression does not occur where it is expected. This non-systematic nature of tonal-depression occurence may be an indication of a recent development of this phonetic feature. The example in (19) shows that tonal depression does not occur where it should otherwise be expected.

Non-occurrence of depression

n\|ui HL (Kua) $\rightarrow$ g\|ui HL (Cua, Tsua) $\rightarrow$ n\|ui HL 'fat, oil'

The phenomenon of tonal depression triggered by voiced plosives is curious among these Eastern Kalahari Khoe languages. It could be a linguistic contact feature, taken from southern Bantu languages (in this case, Kalanga) with which they came into contact (Cashdan 1979). However, this issue will require further investigation to determine the extent and its significance in the phonology of the eastern languages.

\subsection{The PGN system}

The grammatical elements discussed in this section are pronominal markers used in declarative sentences. They are characterised by the grammatical features of person, gender and number. This system is extensive and also varies according to object position as well as relative and genitive forms. Subject and object PGN markers take other subtle distinctions of singularity, duality and plurality. Their pragmatic functions indicate inclusivity and exclusivity, and their neutrality or unmarkedness. For quick illustration and comparison, only the declarative (or nominative) pronominal elements of the three languages - Kua, Cua and Tsua - are presented 
and discussed here. However, it is necessary to mention at this point that there are also accusative (or objective) forms that match the nominative (declarative) forms. The nominative (subjective) and the accusative (objective) forms differ in their vowel suffixes - [-e] for declarative and [-a] for accusative (objective) forms.

Table 2. Declarative subject PGN in Kua, Cua and Tsua

\begin{tabular}{|c|c|c|c|}
\hline Kua & Cua & Tsua & Gloss \\
\hline ce & cíé & cíè & $\mathrm{I}(\operatorname{mix} .1 \mathrm{SG})$ \\
\hline átsèbè & àtsábé & ítsábè & we (masc. $1^{\text {st }}$-pers.dual) \\
\hline ítsèbè & ítsábé & ítsábè & we (masc. $1^{\text {st }}$-pers.dual.excl.) \\
\hline ásèbe & àsábé & ísábè & we (fem. $1^{\text {st }}$-pers.dual) \\
\hline ísèbè & ísábé & ísábè & we (fem. $1^{\text {st }}$-pers.dual.excl.) \\
\hline ákhèbè & àkhábé & - & we (mix. $1^{\text {st }}$-pers.dual) \\
\hline íkhèbè & íkhábé & íkhábè & we (mix. $1^{\text {st }}$-pers.excl.) \\
\hline állè & àláé & - & we (masc. 1PL) \\
\hline íllè & íláé & íllá é & we (masc. 1PL.excl.) \\
\hline ásè & à)éé & ísíè ; ízíè & we (fem. 1PL) \\
\hline ísè & íféé & ízíè & we (fem. 1PL.excl.) \\
\hline átè & àtáé & ítáè & we (mix. 1PL) \\
\hline ítè & ítáé & ítáè & we (mix. 1PL.excl.) \\
\hline tséè & tsáé & tsá è & you (masc. 2SG) \\
\hline séè & sáé & sá è & you (fem. 2SG) \\
\hline ítsò & ítsóé & ítsóè & you (masc. $2^{\text {nd }}-$ pers.dual) \\
\hline ísò & ísóé & ísóè & you (fem. $2^{\text {nd }}-$ pers.dual) \\
\hline íkho & íkhóé & íkhóè & you (mix. $2^{\text {nd }}$-pers.dual) \\
\hline íllò & íllóé & íllóè & you (masc. 2PL) \\
\hline ídzò & ídzóé & ízóè & you (fem. 2PL) \\
\hline ítfò & ítóé & Ítóè & you (mix. 2PL) \\
\hline àbè & èbé & èbè & he (masc. 3SG) \\
\hline àsè & èsé & èsè & she (fem. 3SG) \\
\hline àtsère & ètsèrè & ètsèrè & they (masc. $3^{\text {rd }}$-pers.dual) \\
\hline àsèrè & èsèrè & èsèrè & they (fem. $3^{\text {rd }}$-pers.dual) \\
\hline àkhòre & èkhòrè & èkhwèrè & they (mix. $3^{\text {rd }}$-pers.dual) \\
\hline àllòè & èllòè & èllòè & they (masc. 3PL) \\
\hline àdzè & èdzè & èdzè & they (fem. 3PL) \\
\hline àrè & èrè & èrè & they (mix. 3PL) \\
\hline
\end{tabular}

The above examples demonstrate the core function of the PGN system as retained in Eastern Kalahari Khoe languages. This PGN marking system, associated with declarative forms, is an indication that nouns take female, masculine, mixed and unmarked gender features. In terms of syntax, only western varieties retain PGN markers other than subject/object pronominal forms. In Tsua, for instance, the subject pronominal markers, although they are marked for PGN, function in predication as subject-agreement markers (SAMs). In this function, they play a role which, in non-Khoe languages, is taken on by SAMs; an example of the latter is found in 
Setswana, where the minimal predicative structure can canonically be represented as N SAM-V. Here, a noun is followed by an agreement element (concord) which recalls its noun class.

Furthermore, as Table 2 shows, in the eastern varieties, certain pragmatic features such as inclusivity and exclusivity distinctions have been lost or are not commonly used in the expected contexts. However, in Khoe languages, the SAM must still be governed by the gender of the subject noun. The PGN reduction, therefore, is predicated on the observation that western varieties manifest extensive use of these features in comparsion with the eastern speech communities. The reduction creates a minimal (N) SAM (PGN) V predicative structure which is a clear simplification of the west-most presentation, such as in Kua. The examples in (20) to (24) are taken from Collins and Chebanne's (2013-2014) field notes.

(20) PGN in Kua syntax

$\begin{array}{lllll}\text { a. Kié } & \text { kwà ábà g\|àé } & \text { (sà) } & \text { mùù } \\ \text { 1SG } & \text { PROG dog } & \text { female } & \text { FEM.SG } & \text { see } \\ \text { 'I see a female dog' } & & & \end{array}$

The gender marker $s a$ appears to be optional if gender is marked in the noun phrase by g\|lé ('female'). However, when the word $g \|$ àe is omitted, the following occurs.

$\begin{array}{llll}\text { b. Kié } & \text { kwà ábà: } & \text { sà } & \text { mùù } \\ \text { 1SG } & \text { PROG dog } & \text { FEM.SG } & \text { see } \\ \text { 'I see a female dog' } & & \end{array}$

In this case, $s a$, the feminine singular object PGN marker must necessarily appear. So, pragmatically and cognitively, it is the idea of the gender of a noun which is the determinant in the conjugation of these features.

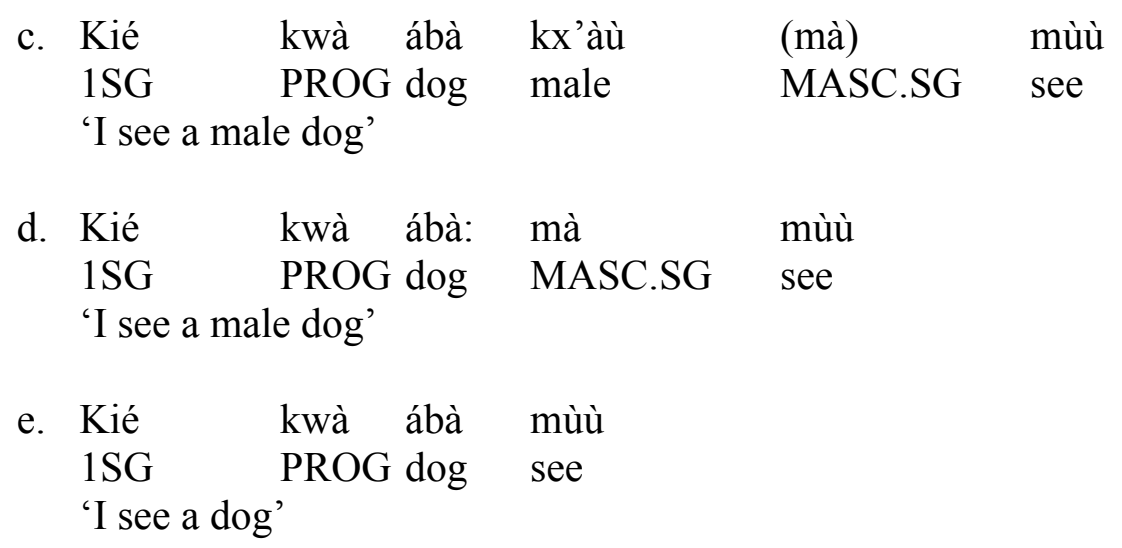

In the Gllana off-shoot represented by Kua, there are more syntactic possibilities in the use of PGN elements. For instance, the PGN can be reduced to a bare unmarked form (20e). It appears as though the bare form of the PGN is used, representing "dog" in this case, when one does not want to express gender or when this is not known. Tsua only uses types of sentences like that in (20e), which do not vary freely. 
(21) Reduction of PGN
a. ábà: sè kwà kú̃ù̃
dog FEM.SG PROG go
'The female dog is going'
b. ábà: bè kwà kứu
dog MASC.SG PROG go
'The male dog is going'
c. ábà: è kwà kú̃ũ
dog NEUT.SG PROG go
'The dog is going'
d. Kié kwà Mpho mà mùù
1SGPROG Mpho MASC.SG see
'I see $\mathrm{Mpho}^{3}$,
e. Mpho mà kyé kwà mùù
Mpho MASC.SG 1SG PROG see
'I see Mpho'

The word orders in (f) and (g) are perfectly felicitous in Kua.
f. Opi bè kwà kú̃ù
Opi MASC.SG PROG go
'Opi is going'
g. Kié kwà Neo sà mú
1SG PROG Neo FEM.SG see
'I see Neo'

The Tsua examples below clearly show that the PGN can drop altogether.

(22) PGN-drop in Tsua
a. Cié kwà Neo mú̃ù
1SGPROG Neo see
'I see Neo'
b. apa (e) kwa mú̃ ù
dog 3SG PROG see
'The dog sees'

Since word order can be variable, the structure in (22) can be re-ordered to put the object in focus. In this case too, the PGN is dropped in Tsua and Cua.

\footnotetext{
${ }^{3}$ Note that, in Setswana, "Mpho" and "Opi" are men's names and "Neo" is a woman's name.
} 
(23) The PGN drop

a. Kua / Cua

$\begin{array}{lll}\text { Neo sà } & \text { kié } & \text { kwà mùù } \\ \text { Neo FEM.SG } & \text { 1SG } & \text { PROG see } \\ \text { 'I see Neo' } & & \end{array}$

b. Tsua
Neo cié kwà mùù
Neo 1SG PROG see
'I see Neo'

When the examples in (21) to (23) are considered, it is clear that in Kua (which is closely related to the western varieties), the PGN is obligatory and doubles for predication and syntactic PGN agreement. However, it remains as a feature of the noun it co-occurs with, and is not independent as well as being unbound. What is independent is the SAM. When examples (22) and (24) are considered, one important observation is that the western varieties give the subject noun the aptitude to head the predication, but the subject noun is not the PGN of this predication. In order to become the head of the predication, the PGN must first be converted to a SAM, that is, into a pronominal element. In Tsua, it is the function of the SAM which is now indispensable and which can also co-occur with the subject noun. Furthermore, the SAM can occur without the noun, and thus it functions as a pronominal element that is a marker for PGN.

(24) The PGN's role as the SAM
a. Kua
$\mathrm{NeO}$
sè
kwà kúũ̃
$\mathrm{Neo}$
3FEM.SG
'Neo is going'
PROG go
b. Tsua
$\mathrm{NeO}$
èsè
kwà kúũ̀
$\mathrm{Neo}$
3FEM.SG
PROG go
'Neo is going'
c. $\frac{\mathrm{Cua}}{\mathrm{Neo}}$
Neo
èsé
kwà kứũ
'Neo is going'
3FEM.SG
PROG go

Place names in the western varieties carry a PGN marker, while in the eastern varieties the marker is not present. However, the noun remains notionally marked for PGN as this is the basis for its aptitude to generate the SAM system. The western varieties have this advantage of overt PGN marking, as illustrated by the examples in (25). 
(25) Marking PGN for place names
a. Kua
Kié kùà Gaborone sì Pòà kứu ł?án
1SG PROG Gaborone FEM.SG LOC go want
'I want to go to Gaborone'
b. Tsua / Cua
Cié kwà Gaborone ?ò kứũ hĩ káā
1SG PROG Gaborone LOC go LOC want
'I want to go to Gaborone'

The above examples show that in the western varieties, all nominal items must be marked for PGN in syntax, while in the eastern varieties place names - even though they are nouns - are not marked for PGN in syntax. Table 2 presented earlier gives a comparison of PGN-marked declarative SAMs.

\section{Discussion}

The few phonological, morphological and syntactic features discussed in this paper demonstrate an evident attrition of clicks and PGNs among speech communities to the east. However, one has to be very careful about the directionality of this reduction. In making the systematic comparisons of these linguistic features, this paper has demonstrated that the fundamental syntactic structure of these languages is minimally similar and that features are added inflectionally and each language community has its linguistic peculiarities. Furthermore, it has been argued that while language contact and associated sociolinguistic dynamics should be taken into account in some of these instances of feature loss, it is the thesis of the paper that there is an apparent regularity in some of these grammatical changes, suggesting natural or historical processes that can be accounted for diachronically.

This paper has sought to answer the question "what have the Eastern Kalahari Khoe languages lost?" An investigation has identified instances of click loss, delayed aspiration loss, and some perturbation associated with vowel nasalisation and where diphthongs appear or correspond to double vowels. However, not all is lost, as there are some instances of gain of tonal depression, vowel nasalisation and the emergence of nasal consonants. Traill and Vossen (1997:29) point out

that the extent of click loss [is] variable in the languages undergoing it and that they [can] be placed on a continuum reflecting the degree to which it [has] spread through the lexicon.

It has been demonstrated in this paper that this attrition of phonetic features is not limited to the identified cases, but may be extensive and may concern many aspects of the grammar of these languages. Internally, Eastern Kalahari Khoe languages are experiencing dynamic syntactic and lexical changes, in addition to phonological evolutions, but not in a similar manner or frequency. Examples from the discussion provide some preliminary observations on the type of clicks and structures that are involved in these changes. The click-reduction continuum can be presented as follows. 


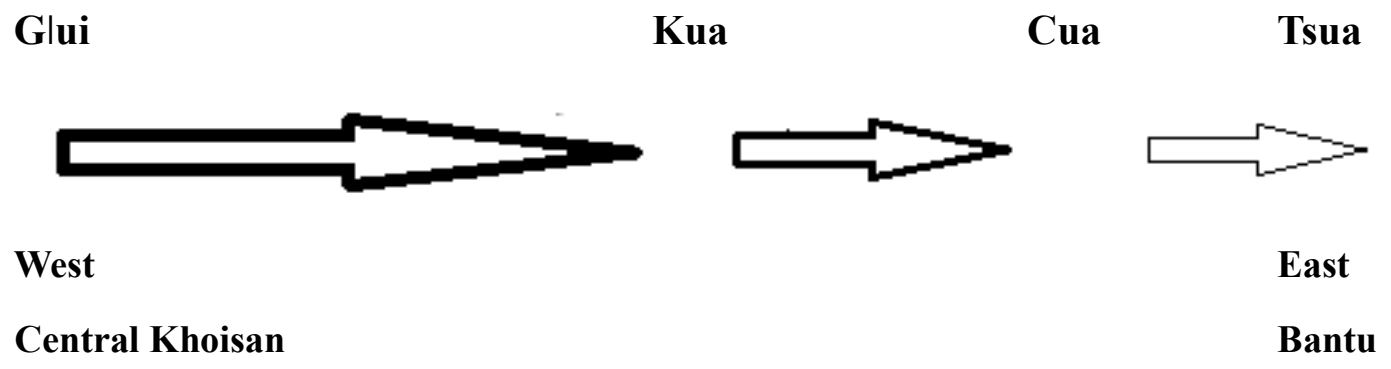

The diagram in (26) summarises the assumption made in this discussion, namely that attrition of grammatical features occurs from west to east within this dialectal continuum. This confirms the findings in the study by Traill and Vossen (1997:51) who, while arguing for the explantion of "ease of articulation" that reglates sound change in Khoisan languages, clearly point to sociolinguistic factors among other facts when they state that:

Click loss is seen as a response by the speakers of certain Khoe varieties to linguistic features (clicks) that are associated with identity as an underclass (Wilmsen and Vossen 1990: 22-23). The reasoning is that clicks are perceived as reinforcing this status because they are regarded as "peculiar" by the economically dominant Bantuspeaking Tswana.

Closer to the linguistically and economically powerful Batswana, the Khoisan languages lose clicks and, subsequently, the people their languages. The sizes of the arrows indicate the intensity of the presence of these features in a speech community. It should be noted that the diagram in (26) does not purport to present any direction of sound changes. In terms of lexical data considered and the phonological characterisation observed, the Eastern Kalahari Khoe makes a sub-cluster comprising Cua and Tsua to the east, and Kua and Glui and Gllana to the west. Kua, as indicated earlier, should not be construed as a particular language but rather as an off-shoot of Gllana to the east.

The present paper therefore proposes an alternative - or possibly complementary - explanation that gives greater weight to the role of language contact. The importance of this contribution is to create a basis for further linguistic study and documentation of the Eastern Kalahari speech communities. It is hoped that this non-conclusive data will lead to some substantial research on the Eastern Kalahari Khoe languages, and that their analysis will clarify their inter-ethnic and linguistic relationships. Such research and documentation is considered very urgent as these languages are no longer passed on to the younger generations. A quick survey conducted in 2013 indicated that the average age of fluent Tsua speakers is 40 years, 30 years for Cua, and 63 for Kua. No one younger than these ages speaks these languages. Due to the adverse language policy in Botswana which militates against minority languages, these languages cannot benefit from development of literacy materials to support the education of children born in these communities. Research in the north-east of this area, among the Shua of Makagadikgadi, will be necessary to complete the picture of these languages and their inter-linguistic relationship(s). 


\section{Conclusion}

This paper has examined some lexical, phonological, morpho-phonological and syntactic features of three languages (Kua, Cua and Tsua) spoken by the Eastern Kalahari Khoe speech communities. The argument for feature loss has been predicated on two considerations: (i) that there is reduction of these phonological features moving from west to east, and (ii) that different vocabulary and therefore different words also account for the reduction observed. The evident phonological processes associated with the changes in click consonants have been identified as palatalisation and aspiration, both of which either cause some epenthesis or modification when applied to clicks. In some instances it is the egressive counterpart that takes the ingressive feature. However, as in all diachronic studies, the directionality of these changes remains a big question. There is evidence from observations in the discussion that Eastern Kalahari Khoe languages have undergone phonological and syntactic evolution both historically and socially. However, if contact phenomena to the east are to be considered, it is most probable that language attrition would socio-historically also be accompanied by some shedding of lexical and grammatical features. The fact is, in the past and still today, the Eastern Kalahari Khoe speech communities have faced negative social attitudes from the non-Khoisan speakers who found them in the region. Furthermore, because of their indigenous means of production, the Eastern Kalahari Khoe communities are the poorest, are prone to negative socio-economic relations and consequently become victims of forced assimilation. The small demography that characterises these speech communities also leave them helpless under the imposing influence of other language groups. These are therefore truly endangered languages that require urgent documentation.

\section{References}

Andersson, L.-G. and T. Janson. 1997. Languages of Botswana. Gaborone: Longman.

Cashdan, E. 1979. Trade and Reciprocity Among the River Bushmen of Northern Botswana. $\mathrm{PhD}$ thesis, University of New Mexico.

Chebanne, A. 2003. The Khoe and San languages and people of Botswana: The current situation. In K.K. Prah (ed.) Silenced voices. CASAS Book Series 34. Cape Town: CASAS pp. 59-102.

Chebanne, A. 2008. A sociolinguistic perspective of the indigenous communities of Botswana. African Studies Monographs 29(3): 93-118.

Chebanne, A. and M. Nthapelelang. 2000. The socio-linguistic survey of the Eastern Khoe in the Boteti and Makgadikgadi Pans areas of Botswana. In H.M. Batibo and B. Smieja (eds.) The future of minority languages in Botswana. Frankfurt: Peter Lang. pp. 79-94.

Dornan, S.S. 1917. The Tati Bushmen (Masarwas) and their language. Journal of the Royal Anthropological Institute 47: 37-112.

Dowson, T.A. and D. Lewis-Williams (eds.) 1994. Contested images: Diversity in southern African rock art research. Johannesburg: Witwatersrand University Press. 
Du Plessis, M. 2009. A Unity Hypothesis for the Southern African Khoesan Languages. PhD thesis, University of Cape Town.

Grimes, B. (ed.) 2008. Ethnologue: Languages of the world. Available online: www.sil.org/ethnologue (Accessed 1 August 2014).

Güldemann, T. and R. Vossen. 2000. Khoisan. In H. Bern and D. Nurse (eds.) Khoisan studies. Cambridge: Cambridge University Press. pp. 99-122.

Hasselbring, S. 2000. A sociolinguistic survey of the languages of Botswana: Sociolinguistic studies of Botswana languages series, Vol. 1. Gaborone: Tasalls Publishing and Books.

Lane, P.J., J. Hermans and C. Molebatsi (eds.) 2001. Proceedings from the Basarwa Research Workshop, 24-25 August 1995, University of Botswana. Gaborone: University of Botswana.

MapQuest.com. Available online: http://www.mapquest.com/maps?country=BW (Accessed 1 August 2014).

Molebatsi, C. 2001. The remote area development settlements and the integration of the Basarwa into the mainstream of Botswana society: The case of Mabisikwa and Manxotae - A research proposal. In P.J. Lane, J. Hermans and C. Molebatsi (eds). Proceedings from the Basarwa Research Workshop, 24-25 August 1995, University of Botswana. Gaborone: University of Botswana. pp. 82-87.

Nakagawa, H. 2006. Aspects of the Phonetic and Phonological Structure of the Glui Language. PhD dissertation, University of the Witwatersrand.

Schapera, I. 1930. The Khoisan peoples of Southern Africa: Bushmen and Hottentots. London: George Routledge and Sons.

Traill, A. and R. Vossen. 1997. Sound change in the Khoisan languages: New data on click loss and click replacement. Journal of African Languages and Linguistics 18(1): 21-56.

Vossen, R. 1988. Studying the linguistic and ethno-history of the Khoe-speaking (Central Khoisan) peoples of Botswana. Botswana Notes and Records 16: 16-35.

Vossen, R. 1997. Die Khoe-Sprachen. Ein Beitrag zur Erforschung der Sprachgeschichte Afrikas. Quellen zur Khoisan-Forschung 12. Cologne: Rüdiger Köppe.

Vossen, R. and K. Keuthmann. 1986. Contemporary studies in Khoisan: In honour of Oswin Köhler: Part 2. Quellen zur Khoisan-Forschung 5(2). Helmut Buske Verlag: Hamburg.

Westphal, E.O.J. 1971. The click languages of southern and eastern Africa. In A. Thomas (ed.) Current trends in linguistics, Vol. 7. The Hague: Mouton. pp. 367-420. 


$\begin{array}{ll}\text { Abbreviations: } & \\ \text { DUAL } & \text { dual plural marker } \\ \text { EXCL. } & \text { exclusive marker } \\ \text { FEM. } & \text { feminine form } \\ \text { INCL. } & \text { inclusive marker } \\ \text { LOC } & \text { locative marker } \\ \text { MASC. } & \text { masculine form } \\ \text { MIX. } & \text { mixed gender (feminine + masculine) form } \\ \text { NEUT. } & \text { neutral } \\ \text { num. } & \text { number } \\ \text { PERS. } & \text { person } \\ \text { PGN } & \text { person, gender and number } \\ \text { PL } & \text { plural marker } \\ \text { PROG } & \text { progressive marker } \\ \text { SAM } & \text { subject-agreement marker } \\ \text { SG } & \text { singular }\end{array}$

